\title{
The Effective Dose Analysis of Head CT-Scan on Adult Patients
}

\author{
Febriana Dwi Rahmadani ${ }^{1}$, R Arif Wibowo ${ }^{1}$, Khusnul Ain ${ }^{1}$ \\ ${ }^{1}$ Department of Physics, Faculty of Science and Technology, Universitas Airlangga, Surabaya 60115, Indonesia \\ a) Corresponding author: k-ain@ fst.unair.ac.id
}

Article History

Received : 05 April 2021, Revised : 03 May 2021, Accepted : 26 May 2021, Online : June 2021

\begin{abstract}
This study was aimed to determine the difference of the effective dose from the clinical and theoretical on the head CT-Scan examination of adult patients and compare the data with the permitted dose limit from BAPETEN. The data collected at Haji Hospital Surabaya using MSCT Siemens Somatom Definition AS 64 Slice on five adult patients, aged between 28-67 years old. The step before the scanning process were adjusting the voltage $(\mathrm{kV})$ and current values $(\mathrm{mA})$ on the CT-Scan. The scanning duration for each patient was $4 \mathrm{~s}$ and resulted in head images with CTDIvol and DLP values displayed on the monitor screen. The effective dose limit value for the head CT scan was $2.8 \mathrm{mSv}$, according to BAPETEN. The study results showed that the effective dose on head CT Scan examination was below the safe dose limit value, while the different fractions between the clinical and theoretical of Patient A, B, C, D, and E was 4.11\%; 5.46\%; 6.19\%; 6.52\%; and $5.42 \%$, respectively.
\end{abstract}

\section{INTRODUCTION}

The Computed Tomography Scan (CT-Scan) is commonly used to diagnose inner body illness and abnormality. CT-Scan used ionizing radiation, especially X-rays, to form the human body into a transparent object, so it was easier to obtain information without surgical operations. There are various types of examinations, such as head, thorax (chest cavity), abdomen (abdominal cavity), etc. Head CT-Scan is a type of widely performed examination compared to the other parts of the body. During the scanning process, the patient will receive radiation from the CT-Scan plane. Therefore, it is necessary to calculate the amount of the given radiation dose because the lowest radiation can also affect the biological system and cancer risk on sensitive organs.

The biological effects caused by radiation also depend on the biological sensitivity of the tissue or organ, which also called the effective dose. The effective dose is the radiation dose from different biological sensitivities [1]. The previous study proved that the organ with the largest dose equivalent was the kidney, ranging from 32-140 mGy with the received effective dose of $64 \mathrm{mSv}$ using MSCT Scan GE Lightspeed VCT 64 Slice type on whole abdomen 3 phase examination [2].

\section{MATERIALS AND METHOD}

This study used a Computed Tomography Scan (CT-Scan) and computer to analyze five adult patients aged between 28-67 years old. The primary data results include (kV), (mA), CTDI_vol (mGy), and DLP (mGy.cm). The effective dose was obtained by calculating CTDI_vol and DLP values as the clinical data and compared to the theoretical results. The effective dose was the absorbed dose that depended on the radiation quality and the sensitivity of the tissue. 


\section{RESULTS AND DISCUSSIONS}

TABLE 1. Head CT-Scan Patients Data

\begin{tabular}{ccc}
\hline Patient & Gender & Age (years) \\
\hline A & Female & 28 \\
B & Male & 46 \\
C & Male & 50 \\
D & Male & 53 \\
E & Female & 67 \\
\hline
\end{tabular}

This head CT-Scan study used adult patients aged between 28-67 years old as the samples, as shown in Table 1. The voltage used was $120 \mathrm{kV}$, and the current was below $300 \mathrm{~mA}$ at the Haji Public Hospital Surabaya.

TABLE 2. Head CT-Scan Clinical Data

\begin{tabular}{ccccc}
\hline Patient & mA & $\boldsymbol{C T}_{\boldsymbol{D I}} \boldsymbol{~}_{\boldsymbol{v o l}}(\mathbf{m G y})$ & DLP $(\mathbf{m G y} . \mathbf{c m})$ & $\begin{array}{c}\text { Effective Dose }(\mathbf{m S v}) \\
\mathbf{k}=\mathbf{0 , 0 0 2 1}\end{array}$ \\
\hline A & 206 & 33,58 & 592 & 1,243 \\
B & 206 & 33,58 & 610 & 1,281 \\
C & 205 & 48,08 & 851,64 & 1,788 \\
D & 225 & 36,55 & 668 & 1,402 \\
E & 221 & 36,01 & 648 & 1,360 \\
\hline
\end{tabular}

Table 2 showed that each patient had different CTDIvol and DLP values obtained from the monitor and exposed to different effective doses. In this case of data, patient $\mathrm{C}$ was exposed to the highest dose for $1.788 \mathrm{mSv}$, which implied that the higher the CTDIvol and DLP values obtained, the higher the effective dose.

TABLE 3. Head CT-Scan Clinical Data Based on Theoretical Formula

\begin{tabular}{ccccc}
\hline Patient & mA & $\boldsymbol{C T ~ D I}_{\boldsymbol{v o l}}(\mathbf{m G y})$ & DLP (mGy.cm) & $\begin{array}{c}\text { Effective Dose (mSv) } \\
\mathbf{k = 0 , 0 0 2 1}\end{array}$ \\
\hline A & 206 & 33,58 & 537,28 & 1,128 \\
B & 206 & 33,58 & 537,28 & 1,128 \\
C & 205 & 48,08 & 769,28 & 1,615 \\
D & 225 & 36,55 & 584,8 & 1,22 \\
E & 221 & 36,01 & 576,16 & 1,209 \\
\hline
\end{tabular}

From the results of Table 2 and 3, the received effective doses in this study were considered safe doses as the doses were below the limit dose from BAPETEN, $2.8 \mathrm{mSv}$.

\section{CONCLUSION}

1. The effective dose of head CT scan of clinical and theoretical data were safe since below the dose limit set by BAPETEN.

2. The difference fraction between clinical and theoretical data was $6.52 \%$.

\section{REFERENCE}

3. Cunningham, John.1983. The Physics Of Radiology Fourth Edition. Illinois : Charles C Thomas Publisher.

4. Munir, Misbahul, 2011. Dosis Radiasi dan Faktor Resiko pada Pemeriksaan Computed Tomography Scan Whole Abdomen 3 Fase, Fakultas Matematika dan Ilmu Pengetahuan Alam, Program Studi S1 Fisika, Depok. 